\title{
Detection of novel marine methanotrophs using phylogenetic and functional gene probes after methane enrichment
}

\author{
Andrew J. Holmes, ${ }^{1}$ Nick J. P. Owens ${ }^{2}$ and J. Colin Murrell ${ }^{1}$ \\ Author for correspondence: J. Colin Murrell. Tel: +44 1203 523553. Fax: +44 1203523568. \\ e-mail: CM@dna.bio.warwick.ac.uk
}

1 Department of Biological Sciences, University of Warwick, Coventry CV4 7AL, UK

2 Department of Marine Sciences and Coastal Management, University of Newcastle-upon-Tyne, Newcastle-upon-Tyne, UK

\begin{abstract}
A major limitation of rRNA-targeted group-specific probes is that they may cross-react with organisms of other physiological, or even phylogenetic groups when applied to environmental samples containing unknown sequences. We have exploited the restricted physiology of methane-oxidizing bacteria to assess the specificity and efficiency of probes for this physiological type which target the 165 rRNA or genes involved in methanotroph physiology. Seawater samples were enriched for methanotrophs by addition of methane and essential nutrients. The changes in composition of the bacterial population were monitored by analysis of 165 rRNA gene libraries. Methanotroph groupspecific probes failed to give a signal with samples from these enrichments even though a methanol dehydrogenase structural gene was detected. A 165 rDNA sequence that was abundant only after methane addition was recovered and found to show a close phylogenetic relationship to Methylomonas. Organisms containing this sequence were observed in enrichments by in situ hybridization. The combination of enrichment on methane and screening with the broad specificity methanol dehydrogenase probe allowed detection of novel methanotrophs that were not detected with the original suite of methanotroph group-specific probes.
\end{abstract}

Keywords: 16S ribosomal RNA, marine methane-oxidizing bacteria, oligonucleotide probe

\section{INTRODUCTION}

Methanotrophs are a group of bacteria physiologically defined by their ability to use methane as sole source of carbon and energy for growth. The methanotrophs have attracted the attention of microbiologists for two principal reasons: their biotechnological potential (Oldenhuis \& Jannsen, 1993) and their importance in the global methane cycle (Reeburgh et al., 1993). The contribution of marine systems to the global methane cycle is generally poorly understood. Methane concentrations and oxidation rates have been determined from many oceanic sites. These data have shown the upper ocean is usually methane supersaturated with respect to the atmosphere. Both methane fluxes and oxidation rates in stratified water columns (Ward et al., 1987) and at the air-sea interface (Conrad \& Seiler, 1988) suggest that biological oxidation

Abbreviations: ANMS, ammonium nitrate mineral salts; NMS, nitrate mineral salts; OTU, operational taxonomic unit; sMMO, soluble (cytoplasmic) methane monooxygenase. is occurring in the sea although the methane turnover time may be slow (reviewed by Kiene, 1991). As in the terrestrial environment, methane-oxidizing bacteria are believed to be responsible for this oxidation process.

Although a large number of different methanotrophs have been isolated from soil and freshwater environments (Bowman et al., 1993; Hanson \& Wattenberg, 1991) there have been relatively few reports on the isolation of methanotrophs from the marine environment (Sieburth $e t$ al., 1987; Lidstrom, 1988; Lees et al., 1991; Sieburth et al., 1993). Originally described as Metbylomonas species, these marine strains have now all been reclassified as members of the genus Metbylobacter (Bowman et al., 1993). The lack of diversity of marine methanotrophs in culture may be due to the difficulties in isolation of these organisms. These cultural problems may have led to members of other methanotroph genera being overlooked in marine habitats.

Recent advances in microbial ecology (Ward et al., 1992) make it possible to construct nucleic acid probes for 
phylogenetic, and in some cases physiological groups of bacteria which can be directly applied to the environment (Manz et al., 1992; Wagner et al., 1994; Brusseau et al., 1994). The most widely used strategies involve detection or retrieval of $16 \mathrm{~S}$ rRNA sequences which enable characterization of communities in terms of the phylogenetic position of their component taxa (Britschgi \& Giovannoni, 1991; Schmidt et al., 1991). Application of a $16 \mathrm{~S}$ rRNA-oriented molecular ecology approach to study a physiologically defined group of bacteria requires the pre-existence of a representative culture collection. The isolation, or identification, of a greater diversity of marine methanotrophs is therefore necessary if these kinds of techniques are to be used to assess the role of methanotrophs in the marine methane cycle. We are attempting to achieve this by exploiting the existing knowledge of methanotroph physiology and phylogeny to facilitate the retrieval of new DNA sequences from the environment.

Recent studies on the phylogeny of extant methanotrophs derived from 16S rRNA sequence analysis (Bowman, 1992; Tsuji et al., 1990; Bratina et al., 1992; Brusseau et al., 1994) have shown that they are of two types. Type I methanotrophs contain bundles of intracytoplasmic membranes, assimilate carbon via the ribulose monophosphate pathway and are $\gamma$-Proteobacteria. Type II methanotrophs, which possess intracytoplasmic membranes arranged around the periphery of the cell and use the serine pathway for carbon assimilation, cluster in the $\alpha$-Proteobacteria. Within the $\alpha$ - and $\gamma$-subdivisions, neither group of methanotrophs has any close relatives which are not methanotrophic. This, coupled with the restricted metabolic potential of these organisms, has led us to speculate that phylogenetic position may be a reliable indicator of physiology and that we could exploit this knowledge for the detection of novel strains of methanotrophs.

The obligate nature of methanotrophs allows highly selective enrichment conditions to be established. In this study, bacterial populations in seawater were characterized by analysis of $16 \mathrm{~S} \mathrm{rDNA}$ genes from gene libraries constructed via PCR from total DNA. We report the detection of changes in community structure after methane addition under various enrichment regimes and the enrichment of organisms which show a close phylogenetic relationship, on the basis of $16 \mathrm{~S}$ rRNA signature sequences, to previously isolated terrestrial methanotrophs. Despite their identification using molecular microbial techniques, it was not possible to grow these novel methanotrophs in pure cultures in the laboratory.

\section{METHODS}

Seawater sampling and enrichment cultures. Surface seawater (1-3 m depth) was collected in sterile large glass jars from several locations in the North Sea, the English Channel (Plymouth; February 1993) and the Bristol Channel (Penarth; August 1993). Samples were transported to the laboratory at ambient temperature and enrichments set up as described below.

Large-scale enrichment cultures. A batch culture was established in a 201 working-volume fermentation vessel (LH100 series). The basal medium was the ammonium nitrate mineral salts (ANMS) of Whittenbury et al. (1970) at $0.4 \times$ concentration supplemented with $3.4 \%(\mathrm{w} / \mathrm{v}) \mathrm{NaCl}$. Ten litres of this basal medium was sterilized by autoclaving and inoculated with $10 \mathrm{l}$ of seawater to give a final strength of $0 \cdot 2 \times$ ANMS. $\mathrm{CH}_{4} / \mathrm{CO}_{2}$ mixture $(95: 5, \mathrm{v} / \mathrm{v} ; \mathrm{BOC})$ and air were supplied constantly at 250 and $500 \mathrm{ml} \mathrm{min}^{-1}$, respectively. Temperature and $\mathrm{pH}$ were maintained at $20^{\circ} \mathrm{C}$ and $7 \cdot 6$, respectively. The culture was stirred at 250 r.p.m. and sampled after 1, 3, 5, 7, 10, 14, 21 and $28 \mathrm{~d}$.

Small-scale enrichment cultures. Cultures were established in $250 \mathrm{ml}$ Quick fit flasks sealed with rubber Suba seals. Forty millilitres of basal medium was inoculated with $10 \mathrm{ml}$ seawater. Multiple enrichments were set up for each sample by varying the basal medium. This consisted of ammonium mineral salts, nitrate mineral salts (NMS) or ANMS at $1 \times$ concentration supplemented with 2.5 or $3.4 \% \mathrm{NaCl}$. The $\mathrm{pH}$ was 6.8 or 7.8 and flasks were incubated at either 20 or $30^{\circ} \mathrm{C}$. The Penarth enrichment utilized NMS containing $2 \%$ (w/v) $\mathrm{NaCl}, \mathrm{pH} 6.8$ and was incubated at $30^{\circ} \mathrm{C}$. All flasks were supplied with methane by withdrawal of $50 \mathrm{ml}$ air and injection of $60 \mathrm{ml}$ $\mathrm{CH}_{4} / \mathrm{CO}_{2}(95: 5)$ mixture.

DNA extraction. Nucleic acids were extracted from seawater and the enrichment cultures by the method of Sommerville $e t$ al. (1989). This involved harvesting cells from up to $250 \mathrm{ml}$ of sample by filtration through $0.22 \mu \mathrm{m}$ Sterivex filters (Millipore) and lysis in situ with lysozyme, proteinase $\mathrm{K}$ and SDS treatments. This protocol had been previously demonstrated to lyse all methanotrophs in the University of Warwick culture collection (A. J. Holmes \& J. C. Murrell, unpublished). Nucleic acids were purified from the lysate by ammonium acetate precipitation of proteins, followed by ethanol precipitation to recover nucleic acids. This crude purification procedure yielded high molecular mass DNA of sufficient purity for amplification by PCR from all samples.

Phylogenetic group-specific primers. 16S rRNA sequences of methanotrophs were obtained from GenBank and from Bowman (1992). Regions diagnostic for each of the available representatives of the five genera were selected for probe design. Probe sequences and control organisms are shown in Table 1. The probes were tested for their ability to detect methanotroph genera specifically in both PCR and colony hybridizations against cloned 16S rRNA genes from representative methanotrophs in the University of Warwick culture collection. Reaction conditions for hybridizations and PCR testing were as described below. All probes gave a strong signal with their target genus and showed no cross-reactivity with methanotrophs from other genera. Results of PCR and hybridizations are summarized in Table 1.

Colony hybridization. Host Eschericbia coli containing cloned methanotroph ribosomal RNA genes were grown on nylon membranes placed on LB agar plates containing kanamycin $\left(50 \mu \mathrm{g} \mathrm{ml}^{-1}\right)$ and ampicillin $\left(50 \mu \mathrm{g} \mathrm{ml}^{-1}\right)$. The colonies were lysed and their DNA fixed to the membrane by UV light using standard techniques (Sambrook et al., 1989). Oligonucleotide probes were end-labelled with $\left[\gamma-{ }^{32} \mathrm{P}\right]$ ATP $\left(>100 \mathrm{TBq} \mathrm{mmol}^{-1}\right)$ using $\mathrm{T} 4$ polynucleotide kinase and hybridized overnight to the filters at $50{ }^{\circ} \mathrm{C}$ in hybridization buffer $[6 \times \mathrm{SSC}$ (Sambrook t al., 1989), $0.5 \%$ SDS, $1 \mathrm{mM}$ EDTA, $10 \mathrm{mM}$ sodium phosphate, $\mathrm{pH} 6.8,200 \mu \mathrm{g}$ denatured Herring DNA ml ${ }^{-1}, 1 \times$ Denhardt's solution]. The filters were washed in two changes of $2 \times \mathrm{SSC}$ for 30 min each at $45^{\circ} \mathrm{C}$ and the temperature was raised in $2-5^{\circ} \mathrm{C}$ increments in subsequent washes to determine conditions for the specificity of each probe.

PCR amplification. Bacterial 16S rRNA genes were amplified from all the DNA samples using the bacteria-specific primers f27 and r1492 (Giovannoni, 1991). Amplification reactions were 
Table 1. Methanotroph functional and phylogenetic group-specific probes

\begin{tabular}{|c|c|c|c|c|c|}
\hline \multirow[t]{2}{*}{ Primer } & \multirow[t]{2}{*}{ Sequence $\left(5^{\prime}-3^{\prime}\right)$} & \multirow[t]{2}{*}{ Target genus } & \multirow[t]{2}{*}{ Control organism* } & \multicolumn{2}{|c|}{$\begin{array}{l}\text { Temperature }\left({ }^{\circ} \mathrm{C}\right) \text { for } \\
\text { specificity in: }\end{array}$} \\
\hline & & & & $\begin{array}{c}\text { Colony } \\
\text { hybridization }\end{array}$ & PCR $†$ \\
\hline Mb1007 & САСТСТАCGATCTCTCACAG & Metbylobacter & Mb. albus BG8 & 60 & 58 \\
\hline Mc1005 & CCGCATCTCTGCAGGAT & Metbylococcus & Mc. capsulatus Bath & 55 & 54 \\
\hline $\mathrm{Mm} 1007$ & CACTCCGCTATCTCTAACAG & Metbylomonas & Mm. methanica S1 & 55 & 58 \\
\hline Ms1020 & CCCTTGCGGAAGGAAGTC & Methylosinus & Ms. trichosporium OB3b & 55 & 54 \\
\hline $\mathrm{Mm} 850$ & TACGTTAGCTCCACCACTAA & Metbylomonas & Clone Pen 2 & NT & 58 \\
\hline$m \times a F 1003$ & GCGGCACCAAC'TGGGGCTGGT & $\begin{array}{l}\text { All Gram-negative } \\
\text { methylotrophs }\end{array}$ & Ms. trichosporium OB3b & NT & 59 \\
\hline$m \times a F 1561$ & GGGCAGCATGAAGGGCTCCC & $\begin{array}{l}\text { All Gram-negative } \\
\text { methylotrophs }\end{array}$ & Ms. trichosporium $\mathrm{OB} 3 \mathrm{~b}$ & NT & 59 \\
\hline$m m o C 542$ & GGTTCTGCTGTGCCGCACC & $\begin{array}{l}\text { All sMMO-containing } \\
\text { methanotrophs }\end{array}$ & Ms. trichosporium OB3b & NT & 55 \\
\hline$m m o C 986$ & ATCCCGTGCCGCCGGCGACG & $\begin{array}{l}\text { All sMMO-containing } \\
\text { methanotrophs }\end{array}$ & Ms. trichosporium $\mathrm{OB} 3 \mathrm{~b}$ & NT & 55 \\
\hline
\end{tabular}

NT, not tested.

*Phylogenetic group-specific probes were also tested by a search of the ribosomal database project (Maidak et al., 1994). No nonmethanotroph with two or less mismatches was found for all probes, except Mc1005 which shows homology to some Vibrio spp.

†Primers were also tested against the following strains in PCR, Mb. pelagicus IR-1, Mb. whittenburyi, Mb. luteus, Metbylocystis parvus OBBP and Ms. sporium strain 5.

performed using the reagents supplied with Promega Taq polymerase kits at $1.5 \mathrm{mM} \mathrm{Mg}{ }^{2+}$, with $20 \mathrm{ng}$ template DNA and $100 \mathrm{pmol}$ of each primer added. The reactions were carried out in a Hybaid TR 2 thermocycler with 30 cycles of $92^{\circ} \mathrm{C}$ for $1 \mathrm{~min}$, $60^{\circ} \mathrm{C}$ for $1 \mathrm{~min}$ and $72{ }^{\circ} \mathrm{C}$ for $1 \mathrm{~min}$, with a final extension at $72^{\circ} \mathrm{C}$ for $5 \mathrm{~min}$. Reaction products were checked for size and purity on $1 \%$ agarose gels (Sambrook et al., 1989) and then ligated into the $\mathrm{pCRII}$ vector supplied with the T/A cloning kit (Invitrogen) according to the manufacturer's instructions. Amplifications were also carried out with primers specific for methylotroph genes $(m \times a F$, which encodes the large subunit of methanol dehydrogenase) (Lidstrom et al., 1994), methanotroph genes $\left[m m_{0} C\right.$, which encodes Protein $C$ of soluble methane monooxygenase (sMMO)] (MacDonald et al., 1995) and phylogenetic group-specific primers targeting the $16 \mathrm{~S} \mathrm{rDNA}$ of methanotrophs (Mm1007, Mb1007, Mc1005 and Ms1018). The group-specific primers were used in conjunction with the f27 primer. Primer sequences and the annealing temperatures used in PCR are shown in Table 1.

DNA sequencing. Small-scale preparations of plasmids were made by the method of Saunders \& Burke (1990). All sequencing reactions were carried out using the Sequenase 2.0 sequencing kit (USB) according to the manufacturer's instructions. Single-track ('T-track) sequencing reactions were performed as above except that only the dd'T'TP termination reaction was carried cut. Primers used for the sequencing reactions were complementary to conserved regions of the $16 \mathrm{~S}$ rRNA. Their sequences can be found in Lane (1991) and Giovannoni (1991).

Phylogenetic analysis. Sequences were aligned manually to representative proteobacterial sequences obtained from the Genbank database and dendrograms constructed using the programs DNADIST, FITCH and DNAPARS from the PHYLIP version
3.4 package (Felsenstein, 1988). Only regions which could be unambiguously aligned were included in the analyses (bases $220-450,482-836,850-1133,1140-1284$ and 1287-1430 according to the $E$. coli numbering system). Analyses were also performed with partial sequences to check for the presence of chimaeric sequences. Secondary structure predictions for methanotroph 16S rRNAs were constructed manually, based on the published models of Neefs et al. (1991) and Gutell et al. (1994).

In situ hybridization experiments. The oligonucleotides Mm650 (5' CCTCTACTCAACTC'TAGT) and Mm850 (5' TACGTTAGCTCCACCACTAA) were obtained from Genosys Europe with rhodamine groups attached via a $\mathrm{C}_{6}$ linker at the $5^{\prime}$ terminus. These probes are specific for the Methylomonas lineage (sensu Bowman et al., 1993) and bind to bases $650-677$ and 850-869 of the small-subunit rRNA (E. coli numbering). Binding of the probes to clone Pen 2 was tested in PCR using the amplification conditions described above.

Cultures were sampled after 1-2 d incubation (late exponential phase of growth) and fixed as described by Amann et al. (1990). A $100 \mu \mathrm{l}$ aliquot of fixed cells was mixed with $10 \mu \mathrm{l} 1 \%(\mathrm{v} / \mathrm{v})$ Triton X-100 and collected by centrifugation. The cells were resuspended in $0 \cdot 1 \%$ Triton $\mathrm{X}-100$ to a concentration of approximately $10^{9}$ cells $\mathrm{ml}^{-1}$. Three microlitres of this suspension were applied to the surface of gelatin-treated slides (Amann et al., 1990) and allowed to dry. The cells were then dehydrated by immersion for $3 \mathrm{~min}$ each in a graded ethanol series $(50,80,96 \%)$ and thoroughly air-dried.

Ten microlitres of hybridization solution $[900 \mathrm{mM} \mathrm{NaCl}$, $20 \%$,v/v, formamide, $0.01 \%$ SDS, $20 \mathrm{mM}$ Tris $/ \mathrm{HCl}$, $\mathrm{pH} 7 \cdot 2,30 \mathrm{ng}$ oligonucleotide probe (Manz et al., 1992)] 
was added and the slides incubated in a humidified chamber at $42{ }^{\circ} \mathrm{C}$ for $2 \mathrm{~h}$. The slides were then rinsed in $1 \mathrm{ml}$ wash buffer ( $180 \mathrm{mM} \mathrm{NaCl}, 5 \mathrm{mM}$ EDTA, $0.01 \%$ SDS, $20 \mathrm{mM}$ Tris/HCl, $\mathrm{pH} \mathrm{7.2)}$ to remove the hybridization solution and then immersed in $10 \mathrm{ml}$ wash buffer at $37^{\circ} \mathrm{C}$ for $30 \mathrm{~min}$. Slides were dipped in distilled water before air-drying and mounting in Citifluor AF3 (Citifluor). Slides were examined with a Zeiss Axioskop microscope fitted with filter sets 09 and 15 . The eubacteriaspecific probe Eub338 (Amann et al., 1992) labelled with fluorescein (Genosys Europe) was used as a control for all hybridizations.

\section{RESULTS}

\section{Enrichment for bacteria which could not be obtained in pure culture}

The 201 scale fermenter batch enrichment culture was established to model a marine ecosystem with an excess supply of methane. ANMS (Whittenbury et al., 1970) at $0.2 \times$ concentration, supplemented with $3.4 \% \mathrm{NaCl}$, was used to supply essential trace elements, nitrogen and phosphate for growth. The lower concentration was used to limit potential problems of selection for copiotrophs. The large volume allowed periodic sampling with minimal disturbance of the system. The smaller flask enrichments were designed to rapidly screen samples under a range of growth conditions for cultivable, or at least enrichable methanotrophs.

In the fermenter enrichment of Plymouth seawater, cell numbers remained essentially constant throughout 4 weeks incubation with $\mathrm{CH}_{4} / \mathrm{CO}_{2}$ (95:5) mixture as the sole supplied carbon source. Microscopic examination of the culture showed a mixed bacterial population of approximately $10^{6}$ cells $\mathrm{ml}^{-1}$, consisting mainly of small (1-2 $\mu \mathrm{m})$ rod-shaped bacteria, many of which were motile.

The small-scale flask enrichments were established to obtain samples from a wider geographical range. An enrichment established from the Penarth seawater sample (hereafter refered to as the Penarth culture) was of particular interest. This culture was characterized by its strong pink-orange pigmentation, the growth of cells as aggregated clumps rather than a dispersed culture and the presence of a pellicle in standing cultures. These features are characteristic of the genus Methylomonas (sensu Bowman et al., 1993), representatives of which have not been reported from the marine environment. Numerous attempts to plate out samples from these enrichments were unsuccessful, as had previously been experienced in this laboratory (Lees et al., 1991). Samples from the Penarth enrichment plated on $1.2 \%(\mathrm{w} / \mathrm{v})$ Bacto agar NMS plates incubated in methane/air $(50: 50, \mathrm{v} / \mathrm{v})$ did show orange and pink colonies after a minimum of 1 week incubation at $30^{\circ} \mathrm{C}$. These colonies consisted of tightly bound aggregates of at least three cell types. We were unable to isolate a methanotroph in pure culture from this enrichment.

\section{Construction of 165 rRNA gene libraries}

High molecular mass DNA was readily extracted from all fermenter and batch culture samples. Yields of DNA were approximately $10 \mathrm{ng}$ per $100 \mathrm{ml}$ culture for all fermenter samples, but significantly higher DNA concentrations of $5 \mu \mathrm{g}$ per $100 \mathrm{ml}$ were obtained from the Penarth culture. Two gene libraries, termed Plym and Month, were constructed from 16S rDNA PCR products amplified from the Plymouth seawater sample and the 28-d sample of the fermenter culture. To ensure comparability of the resulting libraries, special attention was paid to ensure DNA extraction, amplification conditions and cloning procedures for these two libraries were reproduced as closely as possible. A third library was also constructed from the Penarth enrichment culture. All three libraries initially contained over 1000 clones of which approximately $80 \%$ contained an insert of the desired size.

\section{Characterization of Plymouth samples}

PCR. The group-specific probes were used in PCR to screen DNA samples for the presence of putative methanotrophs. All probes gave a signal with the relevant control organism [Mm1007 (Metbylomonas methanica), Mb1007 (Metbylobacter albus), Mc1005 (Metbylococcus capsulatus) and Ms1020 (Methylosinus trichosporium)] when used at their specific annealing temperature (Table 1). No PCR amplification product was obtained when total DNA samples isolated from the Plymouth or fermenter samples were used as template (data not shown). The $m \times a F$ primer set amplified a specific product of the expected size from the 28-d fermenter sample but not from the original Plymouth seawater sample (Fig. 1). This product was confirmed as $m \times a F$ by dot-blot hybridization to a probe generated from the $m \times a F$ gene from $M s$. trichosporium using the methods of McDonald et al. (1995). None of the samples tested positive in PCR for sMMO genes.

Analysis of gene library. The $16 \mathrm{~S}$ rDNA libraries constructed from Plymouth seawater samples were screened by single-track ( $T$ ) sequencing to look for a shift in composition of the 16S rDNA library after enrichment on methane. It was expected that methanotrophic organisms, if present, would form a major component of the Month library. One hundred clones from the Plym library and 50 clones from the Month library were selected as a suitable number to allow recognition of a change in the community structure of these two samples with respect to dominant organisms. Seventy-nine clones from the Plym library and 41 clones from the Month library were found to contain the desired $16 \mathrm{~S}$ rDNA insert. Approximately 300 bases of sequence information were read from each clone, including the variable region 1110-1160 (E. coli numbering). A full (four-track) sequence was included on each gel as a control, to facilitate alignment and interpretation of the T-track sequences. The T-track sequences could be readily aligned to the control sequence and clones were sorted into operational taxonomic units (OTUs) on the basis of unique sequences across this short stretch of the $16 \mathrm{~S}$ rDNA. The majority of OTUs identified (including each of the major clusters) differed by greater 
(a)

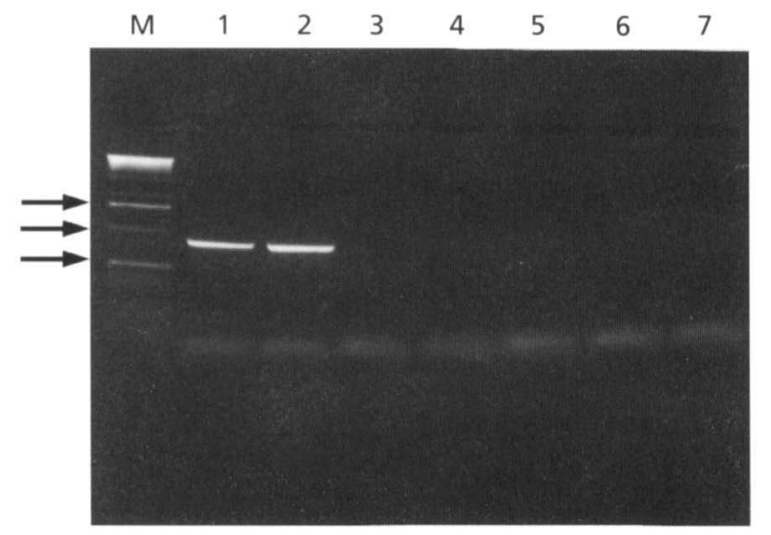

(b)

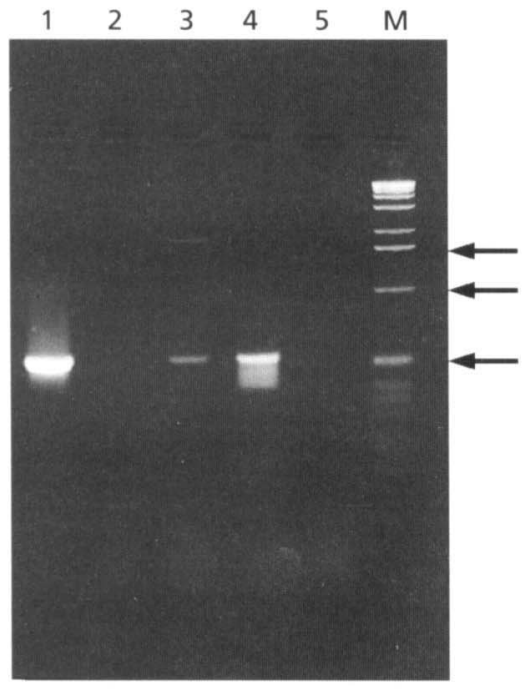

Fig. 1. $P C R$ detection of methylotroph-specific sequences from marine samples after enrichment culture on methane. (a) Amplification of Methylomonas 165 rDNA ( $860 \mathrm{bp}$ ) using the genus-specific primer Mm850 and universal primer f27. Lanes: $M$, molecular mass markers (BRL); 1, Mm. methanica; 2, Penarth enrichment DNA; 3, North Sea Station 1 DNA; 4, North Sea Station 5 DNA; 5, North Sea Station 9 DNA; 6, Ms. trichosporium; 7, Mc. capsulatus. (b) Amplification of mxaF sequences $(558 \mathrm{bp}$ ) from enrichment cultures. Lanes: 1, Penarth enrichment DNA; 2, Plymouth seawater DNA; 3, Plymouth enrichment (Month) DNA; 4, Mc. capsulatus; 5, negative control; $M$, molecular mass markers (BRL). Sizes of markers at 1636,1018 and $506 \mathrm{bp}$ are indicated by arrows on both gels.

than 4 bases. The results of this analysis are summarized in Fig. 2. A total of 36 different OTUs were identified from the two libraries. The majority of these were only represented by a single clone precluding any comment on their relative abundance in the two libraries and only three OTUs were common to both libraries. Nevertheless, a clear difference in community structure, as determined by the $16 \mathrm{~S}$ rDNA gene libraries, between the natural seawater sample and the sample supplied with methane for 1 month was evident, despite the relatively small sample analysed here.
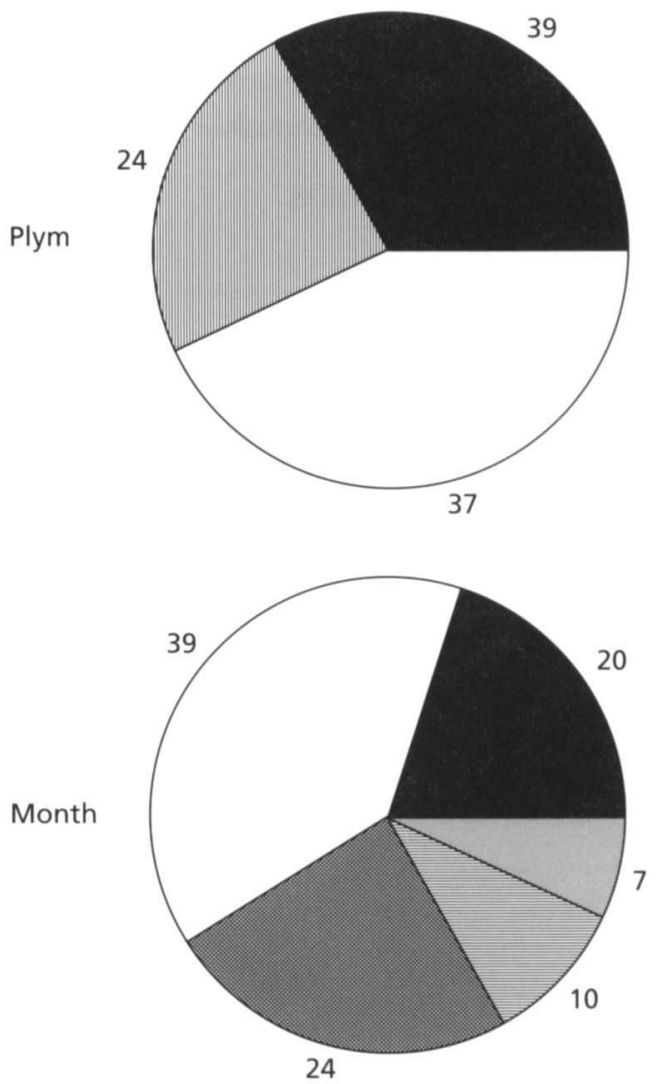

Fig. 2. Proportional representation of OTUs or sequence types, retrieved from the Plym and Month gene libraries, demonstrating the population shift which occurred after enrichment on methane. OTUs represented by less than three clones are grouped in the category 'others' $(\square)$. 四, Plym 1; Plym 5; 自, Mth 1; 8 , Mth 17; 图, Mth 47.

One OTU, the Plym 5 series, was found in both libraries in significant numbers. This group comprised 39\% (31 out of 79 ) of the clones analysed from the Plym library and $20 \%$ ( 8 out of 41 ) of those from the Month library. The most significant difference between the two libraries was that they both contained a second major OTU which was not found in the other library. These were the Plym 1 series which comprised 24\% (19 out of 79) of the Plym library and the Mth 17 series which comprised $24 \%$ (10 out of 41) of the Month library. The Month library also contained two other OTUs with more than two representatives which were not found in the Plym library; these were the Mth 1 (4 clones) and Mth 47 (3 clones) series. These OTUs may also represent taxa which exhibited a significant enrichment between the two seawater samples (natural and enriched).

Phylogenetic analysis. Selected clones from the Mth 17, Mth 1 and Mth 47 series, all of which showed some evidence of enrichment in the methane-supplied seawater, were analysed further. $16 \mathrm{~S}$ rDNA was completely sequenced and examined for any possible relationship to methanotrophs. None of these clones showed any of the methanotroph signature sequences which we had identi- 


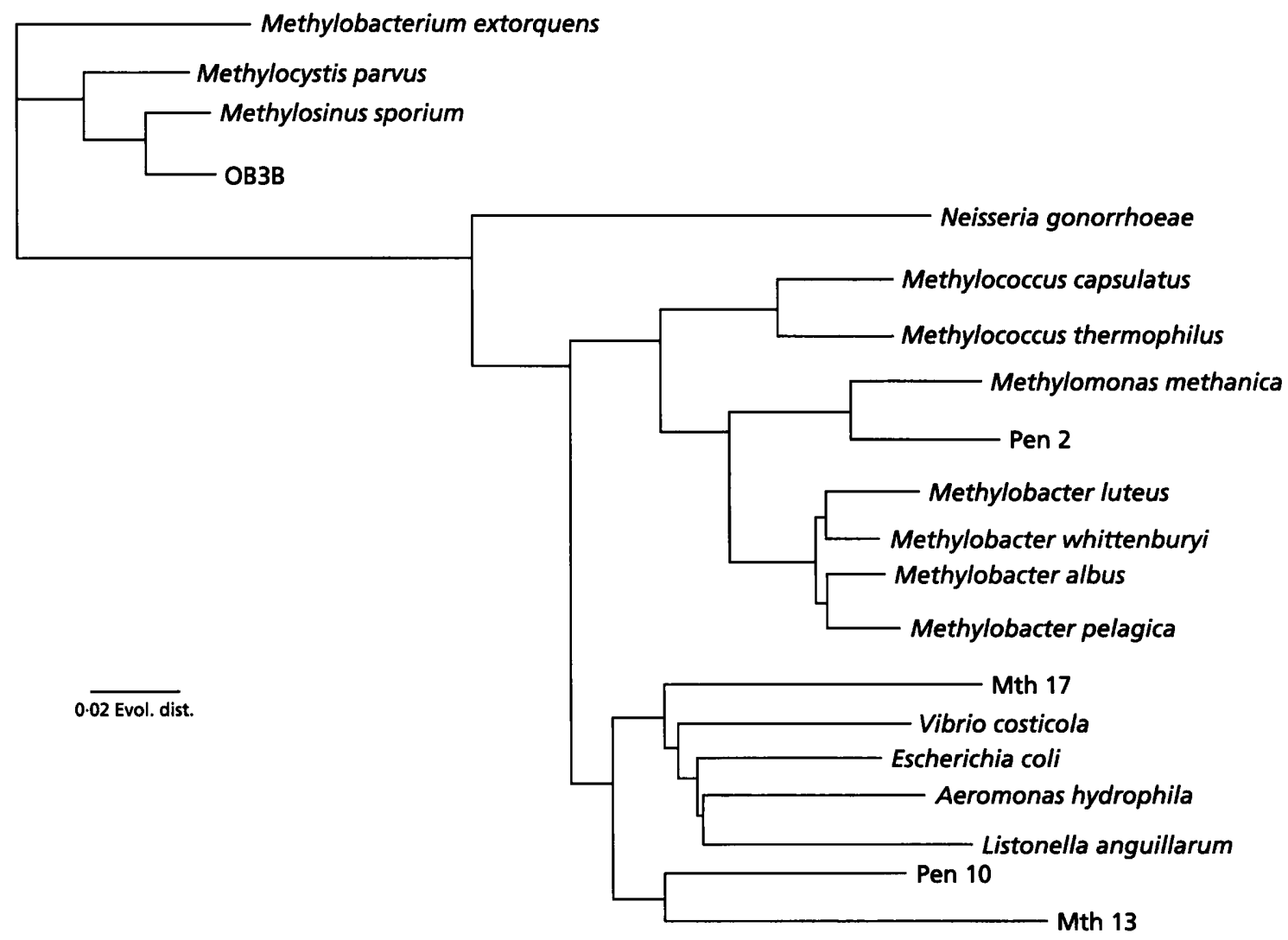

Fig. 3. Unrooted dendrogram showing the phylogenetic position of clones representative of the dominant sequence types retrieved from cultures enriched on methane. Only clone Mth 13 was also found in natural seawater. The position of clone Pen 2 within the radiation of Type I methanotrophs is clearly seen. Clones Pen 10, Mth 17 and Mth13 also branched within the $\gamma$-Proteobacteria but showed no relationship to the methanotrophs. The tree was constructed using the programs DNADIST and FITCH from the PHYLIP version 3.4 package (Felsenstein, 1988). Reference sequences were obtained from GenBank and from Bowman (1992).

fied from analysis of available methanotroph 16S rRNA sequences. Phylogenetic trees constructed by distance matrix and parsimony methods showed all these clones to be members of the $\gamma$-Proteobacteria, but to be distinct from the Type I methanotrophs which are also found in this subclass (Fig. 3). The phylogenetic positions of clones Mth 17 and Mth 13 (a member of the Plym 5 series), examples of the two dominant OTUs in the Month library, are shown in Fig. 3.

\section{Characterization of Penarth samples}

PCR. The Penarth enrichment established in NMS and supplied with methane showed strong bacterial growth, indicating the presence of methanotrophs. Surprisingly, DNA from this sample did not yield a PCR product with any of the methanotroph group-specific primers or sMMO primers under specific (stringent) amplification conditions. A specific PCR product was obtained with the $m \times a F$ primers, confirming the presence of methylotrophs (Fig. 1). Under lower stringency amplification conditions $\left(50^{\circ} \mathrm{C}\right.$ annealing) a faint product was found using the primers $\mathrm{f} 27$ and $\mathrm{Mm} 1007$ from enrichment culture DNA samples but not from the original Penarth seawater sample.
Analysis of 165 rDNA library. Using colony hybridization, 153 colonies were screened for putative methanotroph sequences. Under low stringency conditions $\left(50^{\circ} \mathrm{C}\right)$ the Metbylomonas probe $\mathrm{Mm} 1007$ bound to $49 \%$ (75 out of 153) of colonies and no colonies bound the Metbylobacter probe $\mathrm{Mb} 1007$. Under more stringent hybridization conditions $\left(55^{\circ} \mathrm{C}\right)$ both probes bound only to the controls. These results suggested that a $16 \mathrm{~S}$ rDNA sequence (or sequences) showing significant homology to the $\mathrm{Mm} 1007$ probe constituted about half of this gene library. A further 24 clones were selected from this $16 \mathrm{~S}$ rDNA library and screened by single-track (T-track) sequencing. Two $16 \mathrm{~S}$ rDNA sequence types were found to dominate this small sample. Clones Pen 2 and Pen 10 were selected as representatives of these OTUs and fully sequenced to determine their possible relationship to methanotrophs. Clone Pen 2 showed only 2 mismatches to the $\mathrm{Mm} 1007$ probe and was found to give a positive signal to this probe at $50^{\circ} \mathrm{C}$ in PCR but not at the specific annealing temperature for this probe of $58{ }^{\circ} \mathrm{C}$ (see Table 1).

Phylogenetic analysis. The phylogenetic analysis of clone Pen 2 and clone Pen 10 16S rDNA sequences was carried out as described above. All methods of analysis showed a 


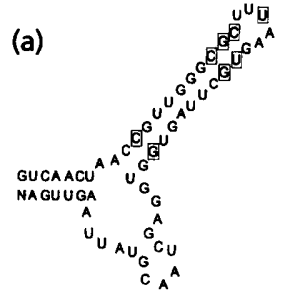

Pen 2

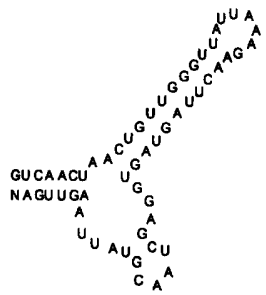

Mm. methanica (b)

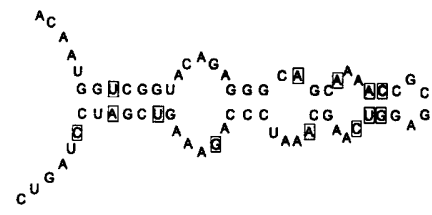

Pen 2

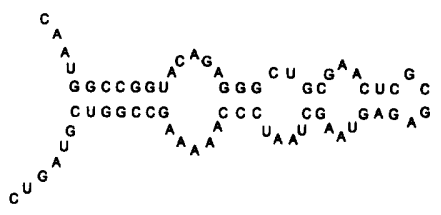

Mm. methanica
Fig. 4. The predicted $16 \mathrm{~S}$ rRNA secondary structures of $\mathrm{Mm}$. methanica and clone Pen 2 for (a) helix 26/27 (bases 821-879) and (b) helix 43/44 (bases 1236-1302). Pen 2 is thought to represent an intact rRNA gene cloned from a mixed culture as the sequence shows a close fit to the bacterial secondary structural model (Neefs et al., 1991). All divergences from its closest relative $\mathrm{Mm}$. methanica (bases boxed in Pen 2) maintain the predicted helix structures by either covariation (both bases of a pair changed) or formation of non-canonical G-U pairs.

close relationship between clone Pen 2 and the Type I methanotroph cluster. Pen 10 also branched within the $\gamma$ Proteobacteria but did not show a close relationship to any of the organisms included in this analysis. Pen 2 showed $95 \%$ similarity to $\mathrm{Mm}$. methanica and consistently branched with this organism, within the radiation of Type I methanotrophs (Fig. 3).

Secondary structure. The derived $16 \mathrm{~S}$ rRNA sequence for Pen 2 showed an excellent correlation to the secondary structure model for small-subunit rRNAs of Gutell et al. (1994). All divergences from the $\mathrm{Mm}$. methanica primary structure could be accommodated within the secondary structural model through compensatory base changes or by formation of non-canonical G-U base pairs. All noncanonical pairs formed in our model for Pen 2 lay in conserved helix motifs. Fig. 4 shows the predicted secondary structures for two regions of the Pen 2 and $\mathrm{Mm}$. methanica 16S rRNA, Helix 27 and Helix 43/44, which are diagnostic for this clone.

In situ hybridization. To confirm the presence of an organism represented by this Pen 2 clone in the enrichment culture, two $5^{\prime}$-rhodamine-labelled oligonucleotides specific for Pen 2 (Mm650 and Mm850) were synthesized, which targeted a different domain (II) of the rRNA than our original set of probes (Mm1007, Mb1007, Mc1005 and Ms1020). These probes were found to be specific for Metbylomonas spp. in PCR and yielded a PCR product from the Penarth enrichment DNA (Fig. 1). Initial experiments using the fluorescein-labelled probe
Eub338 confirmed that both $M m$. methanica and $M c$. capsulatus, harvested from 2-d cultures, were permeable to the oligonucleotide probe and could be easily visualized by fluorescence microscopy. In situ hybridizations using the specific probes Mm650 and Mm850 and the control probe Eub338 were performed on cells from the Penarth enrichments. All cell morphotypes stained with the control bacteria-specific probe Eub338 (Amann et al., 1992) but only a single cell morphotype was stained with the rhodamine-labelled specific probes (data not shown). The 'Pen 2' cells comprised $45 \%$ (averaged over five fields of view) of the Eub338-staining cells in subcultures grown under identical conditions to the primary enrichment culture. This is a similar proportion of the total population to that found with colony blots of the original Penarth culture $16 \mathrm{~S}$ rDNA clone bank using the Mm1007 probe under low stringency conditions and the incidence of the Pen 2 T-track sequence type found in this clone bank.

\section{DISCUSSION}

We have exploited molecular biological methods for the detection of uncultured methanotrophs in marine samples. We have previously noted that despite great difficulties in isolation, methanotrophs are readily enriched from marine habitats. 16S rDNA libraries were used to monitor the shift in bacterial populations that occurred under enrichment conditions highly selective for this physiological type. The use of specific growth conditions limits the number of physiological modes which can be supported in the system, simplifying the task of interpreting physiology from phylogenetic position and facilitating the evaluation of group-specific probes. We established both low and high cell density cultures by varying concentrations of essential nutrients and incubation temperature. These conditions were expected to select for different species of methanotrophs. The enrichments did not generally support the growth of other marine bacteria. The only cultures showing a significant increase in biomass were those from which methanotrophs or methanotroph-related DNA sequences were detected (see also Lees et al., 1991).

The set of phylogenetic group-specific probes had the necessary range to detect all methanotroph strains in our culture collection. To complement these probes, marine samples were also examined for the presence of $m \times a F$ and mmoC (McDonald et al., 1995). Cultures which gave a signal with either of these functional gene probes, but not the group-specific probes, may represent new methanotroph species unrelated to extant strains. We retrieved $16 \mathrm{~S}$ rDNA sequences from these cultures to test our hypothesis that methanotrophs are indeed a phylogenetically coherent group.

The community analysis approach taken (T-track screening of gene libraries from PCR products) showed sufficient sensitivity and resolution to reveal a population shift in the low cell density enrichment (fermenter containing Plymouth seawater). Some workers have expressed concern as to bias which may be introduced 
into community composition by cell lysis, DNA purification and PCR amplification procedures during the construction of gene libraries (Reysenbach et al., 1992; Ward et al., 1992). We were careful to reproduce experimental conditions as closely as possible for the construction of the two 16S rRNA gene libraries to minimize differential bias. It is difficult to attribute the increase in abundance of Mth 17 type clones from less than $1 \%$ ( 0 out of 79$)$ to over $20 \%$ (10 out of 41 ) solely to experimental bias. This change is unlikely to be entirely due to death of some of the original population as this would have required at least a 20 -fold decrease in total bacterial numbers. The most likely explanation is the limited growth of bacteria represented by the Mth 17 sequence type. Under the culture conditions employed, such growth could only have been via efficient scavenging of organic material, methanotrophy, chemoautotrophy or oxygenic phototrophy. The methylotroph-specific gene $m \times a F$ was present in the Month DNA sample but not the Plym DNA sample. It is likely therefore that a component of the enriched bacterial community has the capacity for methylotrophy. However, using the methanotroph group-specific primers and $m m o C$-specific primers, we could not find direct evidence for methanotrophs in the Month sample. The phylogenetic analysis of representatives of Mth 17, Mth 1 and Mth 47, those OTUs which showed evidence of enrichment, revealed them to be $\gamma$-Proteobacteria. No close relatives from which to infer their physiology were identified. If any bacteria represented by these sequences can grow on methane, then they represent a novel lineage of methanotrophs.

The Penarth enrichment culture showed an increase in biomass. As the only carbon source available to support growth to such high biomass (approx. $5 \times 10^{8}$ cells ml$^{-1}$ ) was methane, methanotrophs must have been present in this system. Such organisms are clearly novel strains as they do not react, under stringent conditions, with any of the group-specific probes for described methanotroph species, but only with the $m \times a F$-specific primers. Dendrograms constructed from phylogenetic analysis of $16 \mathrm{~S}$ rDNA sequences of clone Pen 2 all showed a stable branching position within the radiation of Type I methanotrophs, with its closest relatives being Methylomonas spp. The relationship to Metbylomonas is also supported by phenotypic similarities, particularly the presence of a pink-orange pigment and pellicle formation in enrichment cultures.

The formation of chimaeric sequences (Liesack et al., 1991; Kopczynski et al., 1994) and misincorporation of bases during PCR (Keohavong \& Thilly, 1989) is a possible source of error in molecular phylogenetic analysis. However, the stable branching position for Pen 2 in all analyses and the excellent correlation of its inferred $16 \mathrm{~S}$ rRNA secondary structure to the bacterial model provide strong evidence that it represents an intact 16S rRNA gene cloned from an organism from the enrichment culture. This was confirmed by identification of only one cell morphotype in subcultures of this enrichment using fluorescently labelled oligonucleotide probes specific for the Pen 2 clone. Probes Mm650 and Mm850 target separate structural motifs in the $16 \mathrm{~S}$ rRNA. The abundance of Pen 2 cells in subcultures of the enrichment and of the Pen 2 sequence type in the gene library constructed from the original enrichment was found to be similar by several methods. Clearly the Pen 2 clone is representative of the 16S rRNA of a dominant organism in these marine enrichment cultures. The data presented here indicate that Pen 2 is a Type I methanotroph affiliated to the genus Metbylomonas (as classified by Bowman et al., 1993). It can grow at $\mathrm{NaCl}$ concentrations of up to $3.4 \%$ and does not appear to contain sMMO. This supports our hypothesis that for methanotrophs, phylogenetic position may well be an accurate indicator of physiology. Using the 'population shift' approach, we identified a novel methanotroph which could not be detected by our original set of probes or cultivated using current methods. This strategy will be most useful for those organisms which can be enriched under very specific conditions, and could be extended to any group for which both functional probes (i.e. those targeting genes involved in the expression of the phenotype) and phylogenetic probes are available.

\section{ACKNOWLEDGEMENTS}

This work was funded by the Natural Environment Research Council (Molecular and Genetic Analysis of Marine Systems GST/02/567/0) and the EC Environment Programme.

\section{REFERENCES}

Amann, R. I., Krumholz, L. \& Stahl, D. A. (1990). Fluorescentoligonucleotide probing of whole cells for determinative, phylogenetic, and environmental studies in microbiology. $J$ Bacteriol 172, 762-770.

Amann, R. I., Stromley, J., Devereaux, R., Key, R. \& Stahl, D. A. (1992). Molecular and microscopic identification of sulfate-reducing bacteria in multi-species biofilms. Appl Environ Microbiol 58, 614-623.

Bowman, J. P. (1992). The systematics of methane-utilizing bacteria. $\mathrm{PhD}$ Thesis, University of Queensland, Brisbane, Australia.

Bowman, J. P., Sly, L. I., Nicholas, P. D. \& Hayward, A. C. (1993). Revised taxonomy of the methanotrophs: description of Methylobacter gen. nov., emendation of Metbylococcus, validation of Metbylosinus species and a proposal that the family Metbylococcaceae includes only group I methanotrophs. Int J Syst Bacteriol 43, 735-753.

Bratina, B. J., Brusseau, G. A. \& Hanson, R. S. (1992). Use of $16 S$ rRNA analysis to investigate phylogeny of methylotrophic bacteria. Int J Syst Bacteriol 42, 645-648.

Britschgi, T. B. \& Giovannoni, S. J. (1991). Phylogenetic analysis of a natural marine bacterioplankton population by rRNA gene cloning and sequencing. Appl Environ Microbiol 57, 1707-1713.

Brusseau, G. A., Bulygina, E. S. \& Hanson, R. S. (1994). Phylogenetic analysis and development of probes for differentiating methylotrophic bacteria. Appl Environ Microbiol 60, 626-636.

Conrad, R. \& Seiler, W. (1988). Influence of the surface microlayer on the flux of nonconservative trace gases $\left(\mathrm{CO}, \mathrm{H}_{2}, \mathrm{CH}_{4}, \mathrm{~N}_{2} \mathrm{O}\right)$ across the ocean-atmosphere interface. $J$ Atmos Chem 6, 83-94.

Felsenstein, J. (1988). Phylogenies from molecular sequences: inference and reliability. Annu Rev Genet 22, 521-565. 
Giovannoni, S. J. (1991). The polymerase chain reaction. In Nucleic Acid Techniques in Bacterial Systematics, pp. 177-203. Edited by E. Stackebrandt \& M. Goodfellow. Chichester: John Wiley \& Sons. Gutell, R. R., Larsen, N. \& Woese, C. R. (1994). Lessons from an evolving rRNA: $16 \mathrm{~S}$ and $23 \mathrm{~S}$ rRNA structures from a comparative perspective. Microbiol Rev 58, 10-26.

Hanson, R. S. \& Wattenberg, E. V. (1991). Ecology of methylotrophic bacteria. In Biology of Methylotrophs, pp. 325-348. Edited by I. Goldberg \& J. S. Rokem. Oxford: Butterworth-Heinemann.

Keohavong, P. \& Thilly, W. G. (1989). Fidelity of DNA polymerases in DNA amplification. Proc Natl Acad Sci USA 86, 9253-9257.

Kiene, R. P. (1991). Production and consumption of methane in aquatic systems. In Microbial Production and Consumption of Greenbouse Gases: Methane, Nitrogen Oxides and Halometbanes, pp. 111-146. Edited by J. E. Rogers \& W. B. Whitman. Washington, DC: American Society for Microbiology.

Kopczynski, E. D., Bateson, M. M. \& Ward, D. M. (1994). Recognition of chimeric small-subunit ribosomal DNAs composed of genes from uncultivated microorganisms. Appl Environ Microbiol 60, 746-748.

Lane, D. J. (1991). 16S/23S rRNA sequencing. In Nucleic Acid Techniques in Bacterial Systematics, pp. 115-175. Edited by E. Stackebrandt \& M. Goodfellow. Chichester: John Wiley \& Sons.

Lees, V., Owens, N. J. P. \& Murrell, J. C. (1991). Nitrogen metabolism in marine methanotrophs. Arch Microbiol 157, 60-65.

Lidstrom, M. E. (1988). Isolation and characterization of marine methanotrophs. Antonie Leeunenboek 54, 189-199.

Lidstrom, M. E., Anthony, C., Biville, F., Gasser, F., Goodwin, P., Hanson, R. S. \& Harms, N. (1994). New unified nomenclature for genes involved in the oxidation of methanol in Gram-negative bacteria. FEMS Microbiol Lett 117, 103-106.

Liesack, W., Weyland, H. \& Stackebrandt, E. (1991). Potential risks of gene amplification by PCR as determined by $16 \mathrm{~S}$ rDNA analysis of a mixed-culture of strict barophilic bacteria. Microb Ecol 21, 191-198.

Maidak, B. L., Larsen, N., McCaughey, M. J., Overbeek, R., Olsen, G. J., Fogel, K., Blandy, J. \& Woese, C. R. (1994). The ribosomal database project. Nucleic Acids Res 22, 3485-3487.

McDonald, I. R., Kenna, E. M. \& Murrell, J. C. (1995). Detection of methanotrophic bacteria in environmental samples by using the polymerase chain reaction. Appl Environ Microbiol 61, 116-121.

Manz, W., Amann, R., Ludwig, W., Wagner, M. \& Schleifer, K.-H. (1992). Phylogenetic oligodeoxynucleotide probes for the major subclasses of Proteobacteria: problems and solutions. Syst Appl Microbiol 15, 593-600.

Neefs, J.-M., Van de Peer, Y., De Rijk, P., Goris, A. \& De Wachter, R. (1991). Compilation of small ribosomal subunit RNA sequences. Nucleic Acids Res 19, 1987-2015.

Oldenhuis, R. \& Janssen, D. B. (1993). Degradation of trichlorethylene by methanotrophic bacteria. In Microbial Growth on $C 1$
Compounds, pp. 121-133. Edited by J. C. Murrell \& D. P. Kelly. Andover: Intercept Press.

Reeburgh, W. S., Whalen, S. C. \& Alperin, M. J. (1993). The role of methylotrophy in the global methane budget. In Microbial Growth on C1 Compounds, pp. 1-14. Edited by J. C. Murrell \& D. P. Kelly. Andover: Intercept Press.

Reysenbach, A.-L., Giver, L. J., Wickham, G. S. \& Pace, N. R. (1992). Differential amplification of rRNA genes by Polymerase Chain Reaction. Appl Environ Microbiol 58, 3417-3418.

Sambrook, J., Fritsch, E. F. \& Maniatis, T. (1989). Molecular Cloning: a Laboratory Manual, 2nd edn. Cold Spring Harbor, NY: Cold Spring Harbor Laboratory.

Saunders, S. E. \& Burke, J. F. (1990). Rapid isolation of miniprep DNA for double strand sequencing. Nucleic Acids Res 18, 4948.

Schmidt, T. M., DeLong, E. F. \& Pace, N. R. (1991). Analysis of a marine picoplankton community by $16 \mathrm{~S}$ rRNA gene cloning and sequencing. J Bacteriol 173, 4371-4378.

Sieburth, J. McN., Johnson, P. W., Eberhardt, M. A., Sieracki, M. E., Lidstrom, M. \& Laux, D. (1987). The first methane-oxidizing bacterium from the upper mixing layer of the deep ocean: Metbylomonas pelagica sp. nov. Curr Microbiol 14, 285-293.

Sieburth, J. McN., Johnson, P. W., Church, V. M. \& Laux, D. C. (1993). C1 bacteria in the water column of Chespeake Bay, USA. III. Immunologic relationships in the type species of marine monomethylamine- and methane-oxidising bacteria to wild estuarine and oceanic cultures. Mar Ecol Prog Ser 95, 91-102.

Sommerville, C. J., Knight, I. T., Straube, W. L. \& Colwell, R. R. (1989). Simple, rapid method for direct isolation of nucleic acids from aquatic environments. Appl Environ Microbiol 55, 548-554.

Tsuji, K., Tsien, H. C., Hanson, R. S., DePalma, S. R., Scholtz, R. \& LaRoche, S. (1990). 16S rRNA sequence analysis for determination of phylogenetic relationship among methylotrophs. J Gen Microbiol 136, 1-10.

Wagner, W., Erhart, R., Manz, W., Amann, R., Lemmer, H., Wedi, D. \& Schleifer, K.-H. (1994). Development of an rRNA-targeted oligonucleotide probe specific for the genus Acinetobacter and its application for in situ monitoring in activated sludge. Appl Environ Microbiol 60, 792-800.

Ward, B. B., Kilpatrick, K. A., Novelli, P. C. \& Scranton, M. I. (1987). Methane oxidation and methane fluxes in the ocean surface layer and deep anoxic waters. Nature 327, 226-229.

Ward, D. M., Bateson, M. M., Weller, R. \& Ruff-Roberts, A. L. (1992). Ribosomal RNA analysis of microorganisms as they occur in nature. Adv Microb Ecol 12, 209-286.

Whittenbury, R., Phillips, K. C. \& Wilkinson, J. F. (1970). Enrichment, isolation and some properties of methane utilizing bacteria. J Gen Microbiol 61, 205-218.

Received 28 November 1994; revised 27 February 1995; accepted 12 April 1995. 